\title{
Correction to: Multiple functions of CREB- binding protein during postembryonic development: identification of target genes
}

\author{
Amit Roy ${ }^{1,2}$, Smitha George ${ }^{1}$ and Subba Reddy Palli ${ }^{1 *}$
}

\section{Correction}

Following the publication of this article [1], the authors found that some of the primers listed in Table 1 are not correct. This mistake occurred during assembly of the primer table and the authors apologize for this error. This correction does not change the data included in the paper, their interpretation nor the conclusions drawn.

The corrected version of "Table S1: Sequences of primers used in the experiments" is included in this Correction article (Additional file 1).

\section{Additional file}

\begin{abstract}
Additional file 1: Sequence of primers used in the experiments. Figure S1. Checking the knockdown efficiency in T. castaneum larvae and cDNA library preparation for RNA seq. Figure S2. Normalization of RNA-seq data. Figure S3. Histogram presentation of GO ontology classification with 1306 genes that were downregulated in T. castaneum larvae after CBP knockdown. Figure S4. Epi-factor domains within the downregulated genes (1306) after CBP knockdown in T. castaneum larvae. Figure S5. KEGG pathway analysis. Figure S6. Correlation of gene expression levels of 20 selected genes by comparing both qPCR and RNA-seq data. Supporting Information S1. KEGG pathway analysis output. (PDF $892 \mathrm{~kb}$ )
\end{abstract}

\section{Author details}

'Department of Entomology, College of Agriculture, University of Kentucky, Lexington, KY 40546, USA. ${ }^{2}$ Present address, Faculty of Forestry and Wood Sciences, EXTEMIT-K, Czech University of Life Sciences, Kamýcká 1176, Prague 6, 16521 Suchdol, Czech Republic.

Received: 12 July 2018 Accepted: 13 July 2018

Published online: 06 August 2018

\section{Reference}

1. Roy A, et al. Multiple functions of CREB-binding protein during postembryonic development: identification of target genes. BMC Genomics. 2017;18:996. https:/doi.org/10.1186/s12864-017-4373-3.

\footnotetext{
*Correspondence: rpalli@uky.edu

'Department of Entomology, College of Agriculture, University of Kentucky, Lexington, KY 40546, USA

Full list of author information is available at the end of the article
}

(c) The Author(s). 2018 Open Access This article is distributed under the terms of the Creative Commons Attribution 4.0 International License (http://creativecommons.org/licenses/by/4.0/), which permits unrestricted use, distribution, and reproduction in any medium, provided you give appropriate credit to the original author(s) and the source, provide a link to the Creative Commons license, and indicate if changes were made. The Creative Commons Public Domain Dedication waiver (http://creativecommons.org/publicdomain/zero/1.0/) applies to the data made available in this article, unless otherwise stated. 